\title{
Vaccine-induced protection against Leishmania amazonensis is obtained in the absence of IL-12/23p40
}

\author{
Mayra Xiomara Hernández S. ${ }^{a}$, Thales Augusto Barçante ${ }^{\mathrm{b}}$, Luciano Vilela ${ }^{\mathrm{c}}$, \\ Wagner Luiz Tafuri ${ }^{\mathrm{d}}$, Luís Carlos Crocco Afonso ${ }^{\mathrm{e}}$, Leda Quercia Vieira ${ }^{\mathrm{a}, *}$ \\ a Departamento de Bioquímica e Imunologia, Instituto de Ciências Biológicas/ICB, Universidade Federal de Minas Gerais, \\ 31270-901 Belo Horizonte, MG, Brazil \\ ${ }^{\mathrm{b}}$ Departamento de Parasitologia, Instituto de Ciências Biológicas/ICB, Universidade Federal de Minas Gerais, \\ 31270-901 Belo Horizonte, MG, Brazil \\ ${ }^{\mathrm{c}}$ Centro de Pesquisas, Biomm S/A, 39400-307 Montes Claros, MG, Brazil \\ d Departamento de Patologia, Instituto de Ciências Biológicas/ICB, Universidade Federal de Minas Gerais, \\ 31270-901 Belo Horizonte, MG, Brazil \\ ${ }^{\mathrm{e}}$ Departamento de Ciências Biológicas, Instituto de Ciências Exatas e Biológicas and Núcleo de Pesquisa em Ciências Biológicas, \\ Universidade Federal de Ouro Preto, 35400-000 Ouro Preto, MG, Brazil
}

Received 14 January 2005; received in revised form 1 December 2005; accepted 16 December 2005

Available online 13 January 2006

\begin{abstract}
Protozoa of the genus Leishmania are intracellular parasites of macrophages and may cause diverse clinical forms of leishmaniasis, including cutaneous, diffuse cutaneous, mucocutaneous and visceral leishmaniasis. Infection with $L$. major in mice indicates that a protective immune response is achieved when Th1 cells are developed. Thus, adoptive or vaccine-induced protection against leishmaniasis is largely dependent on cell-mediated immunity and IFN- $\gamma$ production. Induction of a Th1 response is dependent on the presence of IL-12 whilst lymphocytes are activated. This study was aimed at evaluating the role of IL-12 during infection with L. amazonensis and after vaccination with Leishvacin ${ }^{\circledR}$ (killed Leishmania amazonensis promastigotes), since the role of this cytokine in vaccine-induced immunity with this preparation in experimental models or in humans is not yet elucidated. Hence, C57BL/6 interleukin-12-deficient mice (IL-12p40 $0^{-1-}$ ) and wild-type controls (wt) were infected with L. amazonensis and the course of infection, parasite burden and cytokine production were compared. IL- $12 \mathrm{p} 40^{-1-}$ mice were more susceptible to L. amazonensis than wt: lesions and parasite burden were larger in IL-12p40 ${ }^{-/-}$when compared to wt. Interestingly, IL-4 was not produced in the absence of IL-12 in response to infection with $L$. amazonensis. To evaluate the role of IL-12 in the vaccine-induced immunity against L. amazonensis infection, IL-12p40-1- wt mice were vaccinated in the base of the tail and subsequently challenged with $L$. amazonensis in the footpads. Surprisingly, vaccinated IL-12p40 $40^{-1-}$ mice developed smaller lesions and had fewer parasites in footpads than non-vaccinated controls. Lymph node and spleen cells from vaccinated IL-12p40 ${ }^{-/-}$mice did not produce high levels of IFN- $\gamma$ in response do in vitro stimulus with antigen. Hence, partial protection against infection with L. amazonensis could be obtained in the absence of functional IL-12 and a typical Th1 response. (C) 2006 Elsevier B.V. All rights reserved.
\end{abstract}

Keywords: Leishmania; Leishmaniasis; Protozoa; Parasite; Vaccine; Adjuvant; IL-12

\section{Introduction}

Leishmaniasis are parasitic infections of animals and humans caused by different species of a protozoan of the genus Leishma-

\footnotetext{
* Corresponding author at: Departamento de Bioquímica e Imunologia, ICB, Universidade Federal de Minas Gerais, CP 486, 30161-970 Belo Horizonte, MG, Brazil. Tel.: +55 313499 2656; fax: +55 3134992614

E-mail address: lqvieira@icb.ufmg.br (L.Q. Vieira)
}

nia. The clinical manifestations of the diseases are determined by the species of Leishmania that infects the host and by the immune response of the host to parasite [1]. Leishmania amazonensis, a member of the Leishmania mexicana complex, has been isolated from patients with diverse clinical forms of the disease in South American countries, including cutaneous leishmaniasis, diffuse cutaneous leishmaniasis (DCL) and visceral leishmaniasis [2].

A clear paradigm has been established for the role of cytokines in resistance and susceptibility during experimental 
infection with another parasite of the genus, L. major, in inbred mice: IL-4 production by BALB/c mice leads to susceptibility, while IL-12-dependent IFN- $\gamma$ production by most mouse strains leads to macrophage activation and control of parasite growth [3]. However, there is evidence that the host immune response to $L$. amazonensis infection is different from that directed to $L$. major. $\mathrm{C} 3 \mathrm{H}, \mathrm{C} 57 \mathrm{BL} / 6$ and $\mathrm{C} 57 \mathrm{BL} / 10$ mice, which are resistant to $L$. major, develop chronic lesions with persistent parasitism when infected with L. amazonensis [4-7]. The maintenance of chronic lesions is independent of the expression of IL-4 and a corresponding Th2 response [4,5,7]. L. amazonensis triggers early production of IL-12 and IFN- $\gamma$ in C57BL/6 mice similarly to $L$. major [8], but infection of $\mathrm{C} 3 \mathrm{H}$ mice results in production of low levels of IL-12 and IFN- $\gamma$ by antigen-specific CD $4^{+} \mathrm{T}$ cells [5]. In fact, chronic infection by L. amazonensis in $\mathrm{C} 3 \mathrm{H}$ and C57BL/6 mice persists even after administration of exogenous IL-12 [5] or IFN- $\gamma$ [9]. The inability of IL-12 to drive an effective cell-mediated immune response during L. amazonensis infection suggests that the parasite can evoke a potent immunomodulatory mechanism to evade widespread parasite killing and promote a chronic infection. However, lesion development and parasite burden have been shown to be exacerbated by $\mathrm{CD}^{+} \mathrm{T}$ cells $[10,11]$, demonstrating that $\mathrm{T}$ cells are activated during $L$. amazonensis infection and that they contribute significantly to the immuno-pathology of the chronic disease [10]. In addition, suboptimal IFN- $\gamma$ production seems to favor parasite growth [10]. However, the mechanisms responsible for susceptibility of mice to this New World parasite species remain obscure. The importance of understanding the factors involved in the maintenance of this chronic disease is highlighted by the fact that chronic cutaneous leishmaniasis in humans is often correlated with a poor Tcell-mediated immune response [12] or a mixed T-cell response [13].

Adoptive or vaccine-induced protection against Leishmania is largely dependent on cell-mediated immunity, Th1 lymphocytes and IFN- $\gamma$ production [14]. Different antigen preparations, including defined and recombinant antigens, have been demonstrated to induce this type of beneficial response in experimental models [15-18]. During the last 20 years, first generation vaccines composed of killed Leishmania promastigotes and manufactured according to Mayrink et al. [17] have been subjected to clinical trials in Brazil [15,17,19-22]. For the sake of standardization, a more simplified version of the vaccine was produced by a former licensed Brazilian biotechnology company, Biobrás (Montes Claros, MG), using only one Leishmania strain (L. amazonensis strain IFLA/BR/1967/PH8), selected among the five present in the former vaccine.

Since Leishvacin is protective against infection with $L$. amazonensis in association with Corynebacterium parvum in the murine model, we chose this as our model vaccine to evaluate the role of IL-12 in the vaccine-induced protection. C57BL/6 interleukin-12-deficient mice (IL-12p40-/- ) and wild-type controls (wt) were used. Our results show that IL-12 p40 is important in the late control of lesions caused by L amazonensis and that, in its absence, partial resistance to infection is obtained in vaccinated mice.

\section{Materials and methods}

\subsection{Animals}

Female C57BL/6 and BALB/c mice (4-6 weeks old) were obtained from CEBIO (Centro de Bioterismo do Instituto de Ciências Biológicas, UFMG, Belo Horizonte, MG, Brazil). Matrices of mice deficient in the production of the p40 chain of IL-12 by homologous recombination (IL-12p40-1- $)$ in the C57BL/6 mice were kindly provided by Dr. Luiz Vicente Rizzo, Department of Immunology, University of São Paulo (São Paulo, Brazil), and bred in the Gnotobiology and Immunology Laboratory of the Instituto de Ciências Biológicas. During the experiments mice were kept in an animal facility with controlled environmental conditions and environmental barriers. Animals were fed a commercial diet for rodents (Labina-Purina SP, Brazil) ad libitum.

\subsection{Parasites and antigens}

L. amazonensis (IFLA/BR/1967/PH8 strain) and L. major (WHO MHOM/IL/80/Friedlin) promastigotes were grown to stationary phase (5-day-old culture) at $27^{\circ} \mathrm{C}$ in Grace's insect medium (GIBCO Laboratories, Grand Island, NY) with $20 \%$ fetal bovine serum (FBS, HyClone Laboratories, Inc., Logan, Utah), $2 \mathrm{mM}$ L-glutamine, $100 \mathrm{U}$ of penicillin-G-potassium and $100 \mu \mathrm{g}$ of streptomycin sulfate per ml. Leishmania antigen was obtained from stationary-phase promastigotes washed four times in $0.1 \mathrm{M}$ phosphate-buffered saline $\mathrm{pH} 7.3$ (PBS) and adjusted to a concentration of $10^{8}$ organisms $/ \mathrm{ml}$. Parasite suspensions were submitted to four cycles of freezing at $-70^{\circ} \mathrm{C}$ followed by thawing at $37^{\circ} \mathrm{C}$. Antigens were stored at $-70^{\circ} \mathrm{C}$ and thawed immediately before use in cell cultures.

\subsection{Vaccine}

Vaccine was produced and provided by Biobrás (Montes Claros, Brazil). The vaccine strain of L. amazonensis was the same used for infections (IFLA/BR/1967/PH8).

\subsection{Vaccination and infection}

C57BL/6 wild-type (wt) and IL12p40-/- C57BL/6 mice were vaccinated according to Costa et al. [16]. Vaccine was administered subcutaneously in $0.15 \mathrm{ml}$ at the base of the tail. Each animal received two inoculations at an interval of 7 days (unless otherwise stated), each dose containing $100 \mathrm{mg}$ of vaccine protein plus $250 \mathrm{mg}$ of Corynebacterium parvum (Laboratório de Extratos Alergênicos Ltda, Rio de Janeiro, RJ, Brazil). Twenty-eight days after the second dose, animals received a further $10 \mathrm{mg}$ of vaccine, without adjuvant. Control groups in this study were unvaccinated C57BL/6 and IL12p40-1- mice and mice injected with $C$. parvum and saline (no antigen). Seven days after the last booster, animals were challenged with $10^{4} \mathrm{~L}$. amazonensis purified metacyclic promastigotes [23] from stationary phase cultures ( 5 days of culture) in the hind footpad. 
In one experiment, mice were challenged 21 days after the last booster. Lesion size was measured during the course of infection with a dial micrometer and expressed as the difference in size between the infected footpad and the contralateral uninfected footpad.

\subsection{Cell culture and parasite quantification}

Spleen and lymph node (popliteal and inguinal) single cell suspensions were obtained as previously described [8] and cultured at $5 \times 10^{6} \mathrm{ml}^{-1}$ in the presence or absence of antigen preparation for $72 \mathrm{~h}$. Supernatants were collected and used for cytokine assays. Parasites were quantified by limiting dilution, as previously described [24]. The footpads were homogenized using a glass tissue grinder in sterile PBS. Tissue debris was removed by centrifugation at $150 \times g$ and cells were concentrated by centrifugation at $2000 \times g$. Pellets were resuspended in $500 \mu$ l of Grace's supplemented culture medium (see above). $220 \mu \mathrm{l}$ were plated onto culture plates and diluted in log-fold serial dilutions in supplemented Grace's insect tissue culture medium starting with a 1:10 dilution. Each sample was plated in duplicates and read 15 days after the beginning of the culture. Pipette tips were discarded after each dilution to avoid carrying adhered parasites from one well to another. Results are expressed as the negative log of the titer (i.e., the dilution corresponding to the last positive well) adjusted per microgram of tissue.

\subsection{Cytokine assays}

IL-4 and IFN- $\gamma$ were assayed by two-site ELISA as described [8]. IFN- $\gamma$ in the supernatants from spleen or lymph node cell cultures was assayed by two site ELISA using rat antiIFN- $\gamma$ monoclonal antibody (mAb) R46A2 and polyclonal rabbit serum specific for the cytokine. ELISA for IFN- $\gamma$ had a sensitivity of $16 \mathrm{pg} / \mathrm{ml}$. The assay for IL-4 was performed using 11B11 mAb for coating and biotinilated BVD6 mAb as detection of bound IL-4. ELISA for IL-4 had a sensitivity of $15 \mathrm{pg} / \mathrm{ml}$.

\subsection{IgE and antigen-specific IgG1 and IgG2a ELISAs}

Total serum immunoglobulin E (IgE) was quantitated by ELISA. The plates were coated with mouse anti-IgE (clone 2363, Southern Biotechnology, Birmingham, AL, USA) at a 1:500 dilution overnight at $4{ }^{\circ} \mathrm{C}$. Sera were diluted 1:20. After $1 \mathrm{~h}$ incubation at $37^{\circ} \mathrm{C}$, plates were washed. After washing, wells were incubated with biotinylated murine anti-IgE antibody (clone R35-72, Southern Biotechnology) at a 1:500 dilution, washed as above, developed using horseradish peroxidasestreptavidin (Sigma, St. Louis, MO, USA). A positive control was performed using serum from BALB/c mice rendered allergic to ovalbumin (kindly provided by Janaina S. Saldanha and Dr. Denise Carmona, Departamento de Patologia/ICB-UFMG, Belo Horizonte). In order to detect antigen-specific IgG1 and IgG2a, ELISA for specific IgG1/IgG2 antibodies was optimised regarding antigen concentrations, sera and conjugate dilutions. L. amazonensis antigen preparation was derived from in vitro promastigote cultures $(10 \mu \mathrm{g}$ protein $/ \mathrm{ml}$ ) was diluted in $0.1 \mathrm{M}$ sodium carbonate buffer ( $\mathrm{pH} 9)$ and $100 \mu \mathrm{l}$ per well were used to coat flat bottom 96 -well plates overnight at $4{ }^{\circ} \mathrm{C}$. Plates were blocked for $1 \mathrm{~h}$ at $37^{\circ} \mathrm{C}$ with PBS containing $1 \%$ bovine serum albumin (BSA, Sigma). Mouse sera were diluted 1:50 with PBS containing $1 \% \mathrm{BSA}$ and serially diluted in the plate (1:3 dilutions) After $2 \mathrm{~h}$ incubation at $37^{\circ} \mathrm{C}$, plates were washed five times with PBS containing 0.05\% Tween 20 (Sigma, St. Louis, USA). Wells were incubated with goat anti-mouse IgG1 or IgG2a (Southern Biotechnology) at a 1:4000 dilution washed and then incubated with rat anti-goat horseradish peroxidaselabeled antibody (Southern Biotechnology) at a 1:2000 dilution. Absorbance values were read at $492 \mathrm{~nm}$ in a Spectra Max Plus reader (Spectra Max Plus reader Molecular Devices Corporation, Sunnyvale, CA, USA).

\subsection{ELISPOT assays}

IL-4 and IFN- $\gamma$-producing cells were determined by ELISPOT assay. MultiScreen-HA Cellulose Ester filtration 96-well plates (Millopore Corp., Bedford, MA, USA) were coated with $0.5 \mu \mathrm{g} / 50 \mu \mathrm{l} /$ well of anti-IL-4 (clone BVD4-1D11, PharMingen, San Diego, CA, USA) or $0.5 \mu \mathrm{g} / 50 \mu \mathrm{l} /$ well of antiIFN- $\gamma$ (clone R4-6A2, PharMingen) in PBS overnight at $4{ }^{\circ} \mathrm{C}$. The plates were washed twice with PBS and blocked using 5\% FBS in DMEM (Dulbecco's minimal essential medium containing $2 \mathrm{mM} \mathrm{L}$-glutamine, $100 \mathrm{U}$ of penicillin 6-potassium $/ \mathrm{ml}$, $100 \mu \mathrm{g}$ of streptomycin/ml, $25 \mathrm{mM}$ HEPES) for $2 \mathrm{~h}$ at $37^{\circ} \mathrm{C}$. The plates were washed with PBS. Single cell suspension of the popliteal lymph node and spleen cells the infected mice were obtained 5 and 8 weeks post-infection as indicated below. The cells were disassociated with a tissue homogenizer and were resuspended in complete tissue culture medium DMEM containing $10 \%$ FBS and were adjusted to a concentration of $3 \times 10^{5} / 200$ and $1 \times 10^{6} / 200 \mu \mathrm{l} /$ well in 96 -well plates. The plate was incubated with or without $100 \mu \mathrm{l}$ of L. amazonensis antigen $(1 \mathrm{mg} / \mathrm{ml})$ for $20 \mathrm{~h}$ at $37^{\circ} \mathrm{C}$ in a humidified chamber containing $5 \% \mathrm{CO}_{2}$. The wells were washed four times each with $0.01 \%$ Tween 20 in PBS and twice with PBS and overlaid with $0.025 \mu \mathrm{g} / 50 \mu \mathrm{l} /$ well of biotinylated anti-IL-4 (clone BVD624G2, PharMingen) or anti-IFN- $\gamma$ (clone XMG1.2, PharMingen) for $2 \mathrm{~h}$ at room temperature. Subsequently, the plates were washed, treated with 1:2000 dilution of Streptavidin-conjugated alkaline phosphatase (PharMingen) for $1 \mathrm{~h}$ at room temperature and washed six times with $0.01 \%$ Tween-PBS and twice with PBS. The IL-4 or IFN- $\gamma$ secreting cells was visualized by the addition of the substrate 5-bromo-4-cloro-3-indoly phosphate (Sigma-Aldrich, Chicago, IL, USA) diluted to $1 \mathrm{mg} / \mathrm{ml}$ in 0.1 M 2-amino-2-methyl-1 propanol buffer (Sigma-Aldrich) for $30 \mathrm{~min}$. Colorimetric analysis was halted by washing with water. After the plates were dried, the resulting spots were counted on a computer-assisted Immunospot image analyzer (Cellular Technology Ltd., Cleveland, OH, USA). The computerassisted image analyzer has $100 \%$ reproducibility when repeatedly counting the same well using single, defined criteria (data not shown). Results are presented as mean values of ELISPOTs detected in duplicate wells. 

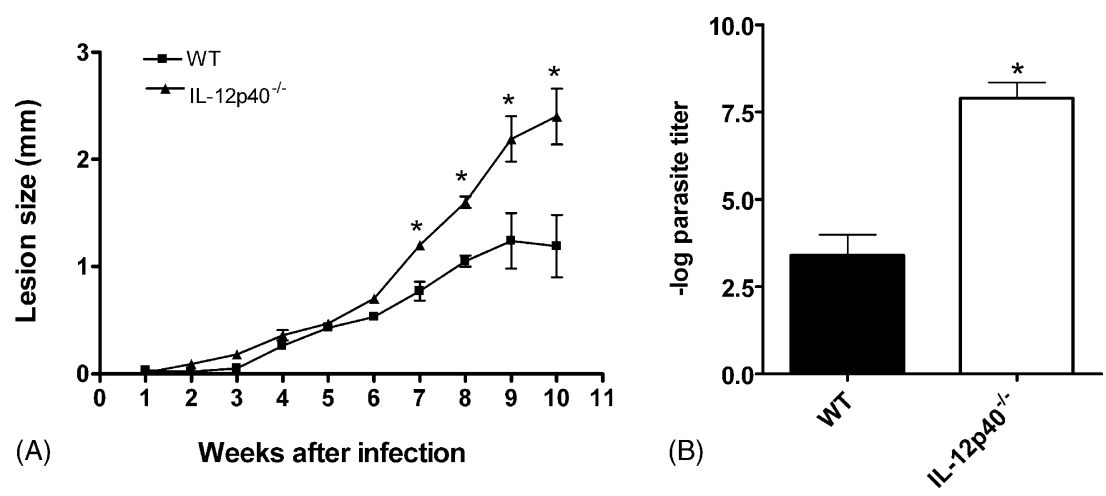

Fig. 1. Course of infection with L. amazonensis in C57BL/6 (wt) and IL-12p40-1- mice. Mice were injected in the left hind footpad with $10^{4}$ stationary-phase promastigotes. (A) Lesion sizes were measured weekly. Each point represents the mean difference in size \pm standard deviation of the mean between infected and uninfected footpads for five mice per group at each time point. (B) Parasite quantification in footpad lesions after 10 weeks of infection. Each bar represents mean \pm standard deviation of the mean for five animals per group. The asterisk indicates a statistically significant difference $(p \leq 0.05)$ compared with the other group.

\subsection{Histopathology}

At the indicated time periods, foot tissues were collected, fixed in a formalin solution and embedded in paraffin. Sections were stained with hematoxylin and eosin. Sections were photographed using an Olympus photomicroscope equipped with an Olympus exposure control unit (Olympus Cop., New Hyde Park, NY).

\subsection{Reproducibility and statistical analysis}

Experiments were performed at least three times. Means were considered statistically different when $p \leq 0.05$ by Student's $t$ test.

\section{Results}

\subsection{Course of infection with L. amazonensis in} IL-12p40 4 - and wt C57BL/6 mice

IL-12p40 $40^{-1-}$ and wt mice were infected with $10^{4} \mathrm{~L}$. amazonensis stationary-phase promastigotes, and lesion progres- sion was monitored (Fig. 1A). Lesions in infected wt mice were at their peak size by 8 weeks and remained constant. IL$12 \mathrm{p} 40^{-/-}$infected mice exhibited quite a distinct pattern of disease. Although lesion sizes could remain similar to the wt group for 6 weeks (Fig. 1A), or even up to 10 weeks (data not shown), at later time points IL-12p40 $40^{-/}$mice developed larger lesions, which progressively increased in size and did not show signs of healing for up to 14 weeks (one experiment performed, data not shown). Parasite burden in IL-12p $40^{-1-}$ mice at 10 weeks of infection was significantly larger (about $10^{4}$ times) than parasite numbers in lesions form wt mice (Fig. 1B). These results show that IL-12p40-/- mice are highly susceptible to infection with L. amazonensis.

\subsection{Cytokine production by C57BL/6 and IL-12p40-1- mice following infection with L amazonensis}

IL-12 is a crucial cytokine for the differentiation of the Th1 subset of helper cells and mice have been shown to default to a Th2 response in the absence of this cytokine $[6,14,25,26]$. In order to determine if the same default response would be found in $L$. amazonensis-infected mice in the absence of IL-12, we

Table 1

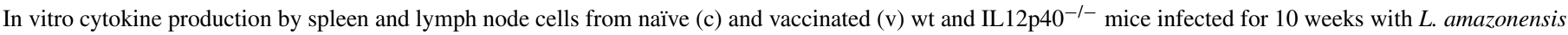

\begin{tabular}{|c|c|c|c|c|c|}
\hline & & \multicolumn{2}{|c|}{ IFN- $\gamma(\mathrm{ng} / \mathrm{ml})$} & \multicolumn{2}{|l|}{ IL-4 (ng/ml) } \\
\hline & & $\mathrm{Bkg}^{\mathrm{a}}$ & $\mathrm{LA}^{\mathrm{b}}$ & $\mathrm{Bkg}$ & LA \\
\hline \multirow[t]{4}{*}{ Spleen } & C57BL/6 c & $6.1 \pm 5.1$ & $9.1 \pm 7.5^{\mathrm{c}}$ & $0.02 \pm 0.01$ & $0.02 \pm 0.01$ \\
\hline & C57BL/6 v & $20.3 \pm 12.2$ & $51.5 \pm 22.7^{\mathrm{d}}$ & $0.04 \pm 0.01$ & $0.04 \pm 0.01$ \\
\hline & IL12p $40^{-1-} \mathrm{c}$ & $0.05 \pm 0.1$ & $0.2 \pm 0.2$ & $0.01 \pm 0.0$ & $0.01 \pm 0.0$ \\
\hline & IL $12 \mathrm{p} 40^{-/-} \mathrm{v}$ & $0.4 \pm 0.5$ & $0.7 \pm 0.7^{\mathrm{e}}$ & $0.01 \pm 0.01$ & $0.02 \pm 0.01$ \\
\hline \multirow[t]{4}{*}{ Lymph node } & C57BL/6 c & $10.5 \pm 7.6$ & $43.2 \pm 20^{c}$ & $0.02 \pm 0.01$ & $0.01 \pm 0.0$ \\
\hline & C57BL/6 v & $61.3 \pm 18.5$ & $140.2 \pm 13^{\mathrm{d}}$ & $0.04 \pm 0.02$ & n.d. \\
\hline & IL12p $40^{-/-} \mathrm{c}$ & n.d..$^{f}$ & $0.9 \pm 1$ & $0.1 \pm 0.0$ & $0.1 \pm 0.0$ \\
\hline & IL $12 \mathrm{p} 40^{-/-} \mathrm{v}$ & $1.8 \pm 1.3$ & $2.1 \pm 1.6^{\mathrm{e}}$ & $0.1 \pm 0.0$ & $0.1 \pm 0.0$ \\
\hline
\end{tabular}

\footnotetext{
a No antigen added to the culture.

b L. amazonensis freeze-thawed antigen added to the culture.

c $P<0.05$ wt c vs. IL $12 \mathrm{p} 40^{-1-} \mathrm{c}$ by Student's $t$-test.

d $P<0.05$ wt v vs. wt c by Student's $t$-test.

e $P<0.05$ wt v vs. IL12p40-1- v by Student's $t$-test.

${ }^{f}$ Not detected. Limits of detection were: $0.016 \mathrm{ng} / \mathrm{ml}$ for IFN- $\gamma$ and $0.015 \mathrm{ng} / \mathrm{ml}$ for IL-4.
} 
(A)

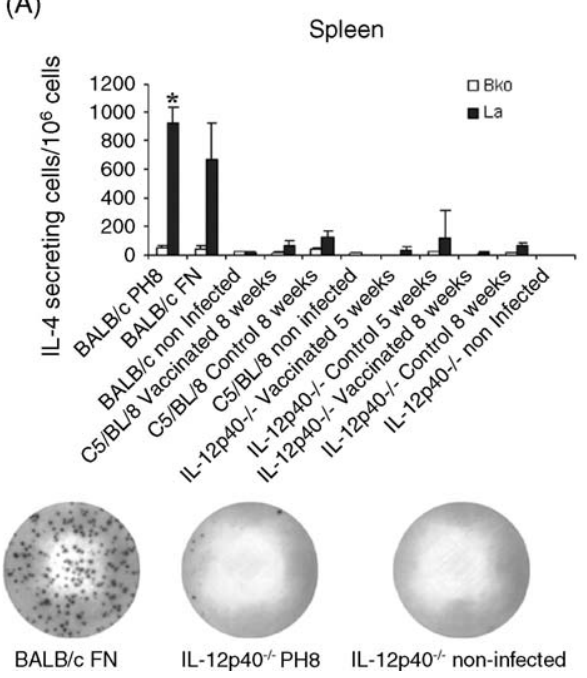

(B)

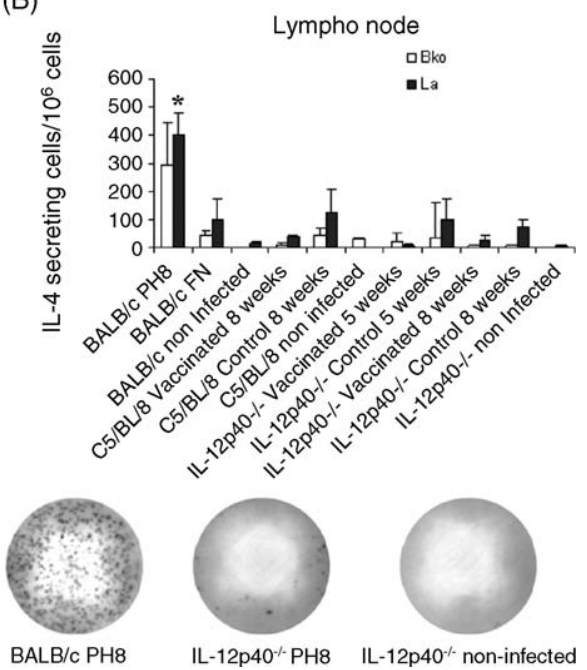

Fig. 2. IL-4-producing spleen and lymph node cells in control and vaccinated C57BL/6 and IL-12p40-/- mice after infection with $L$. amazonensis for 5 and 8 weeks. IL-4 secreting cells were measured by ELISPOT assay. BALB/c mice infected with $L$. major (BALB/c FN) and L. amazonensis (BALB/c PH8) were used as positive controls. Spleen cells and popliteal lymph node cells draining the site of infection were incubated over wells (seeded with $5 \times 10^{5}$ and $1 \times 10^{6}$ cells) that had been precoated with mAbs against IL-4, as described in Section 2. Pictures of IL-4 ELISPOT membranes from the ELISPOT assay are shown at the bottom. Each bar represents mean \pm standard deviation of the mean for five animals per group. The asterisks indicate a statistically significant difference $(p \leq 0.05)$ compared with the other group. Bkg, no antigen added to the culture, LA, L. amazonensis freeze-thawed antigen added to the culture.

determined the cytokine production by spleen and lymph node cells from wt and IL-12p40-/- mice in vitro. Results from a representative experiment are shown in Table 1. Cells from wt mice responded to $L$. amazonensis with IFN- $\gamma$ production, and, quite expectedly, cell cultures from IL- $12 \mathrm{p} 40^{-1-}$ mice produced low levels of this cytokine both in the absence and in the presence of antigenic stimulus. These results were confirmed by ELISPOT: there were no detectable IFN- $\gamma$-producing cells in spleens and lymph nodes of IL-12p $40^{-1-}$ mice infected with $L$. amazonensis, nor in BALB/c mice infected with L. major or $L$. amazonensis (Table 2). Wild-type C57BL/6 mice showed significant numbers of IFN- $\gamma$ producing cells when infected with $L$. amazonensis. Surprisingly, however, IL-4 production was either undetectable or just above the detection limit of the assay in cell culture supernatants from both IL-12p $40^{-/-}$and wt mice of mice (Table 1). These results were confirmed by ELISPOT assays. As shown in Fig. 2, IL-12p $40^{-1-}$ mice did not show an increase in the number of IL-4-secreting cells at 5 or 8 weeks after infection. In addition, we did not find a significant inversion of the $\operatorname{IgG} 1 / \operatorname{IgG} 2 \mathrm{a}$ ratio, nor a significant increase in the

Table 2

Mean IFN- $\gamma$ ELISPOT response by spleen and LN cells in vaccinated and control C57BL/6 and IL-12p40 ${ }^{-/-}$mice after infection with L. amazonensis

\begin{tabular}{|c|c|c|c|c|}
\hline & \multicolumn{4}{|c|}{ IFN- $\gamma$ secreting cells $\left(\text { cells } / 10^{6}\right)^{\mathrm{a}}$} \\
\hline & \multicolumn{2}{|l|}{ Spleen } & \multicolumn{2}{|l|}{ Lymph node } \\
\hline & $\mathrm{Bkg}^{\mathrm{b}}$ & $\mathrm{LA}^{\mathrm{c}}$ & $\mathrm{Bkg}$ & LA \\
\hline $\mathrm{BALB} / \mathrm{c} \mathrm{FN}$ & $0.66 \pm 0.60$ & $0 \pm 0$ & $7.0 \pm 1.6$ & $4.1 \pm 1.6$ \\
\hline $\mathrm{BALB} / \mathrm{c}$ ni & $1 \pm 0.22$ & $0 \pm 0$ & $0 \pm 0$ & $15 \pm 2$ \\
\hline C57BL/6 v 8 weeks & $5.1 \pm 0.82$ & $34.8 \pm 13.44$ & $469 \pm 23.12^{*}$ & $1028 \pm 30.41^{*}$ \\
\hline IL- $12 \mathrm{p} 40^{-1-}$ v 5 weeks & $0 \pm 0$ & $0 \pm 0$ & $0 \pm 0$ & $0 \pm 0$ \\
\hline IL-12p $40^{-/-}$c 5 weeks & $0 \pm 0$ & $0 \pm 0$ & $0 \pm 0$ & $0 \pm 0$ \\
\hline IL-12p $40^{-/-}$v 8 weeks & $0 \pm 0$ & $0 \pm 0$ & $0 \pm 0$ & $0 \pm 0$ \\
\hline IL-12p $40^{-/-}$c 8 weeks & $0 \pm 0$ & $0 \pm 0$ & $0 \pm 0$ & $0 \pm 0$ \\
\hline IL- $12 \mathrm{p} 40^{-/-} \mathrm{ni}$ & $0 \pm 0$ & $0 \pm 0$ & $0 \pm 0$ & $0 \pm 0$ \\
\hline
\end{tabular}

${ }^{\text {a }}$ Spleen cells and poplitean LN cells draining the site of infection were incubated over wells (seeded with $5 \times 10^{5}$ and $1 \times 10^{6}$ cells) that had been precoated with mAbs against IFN- $\gamma$. After undisturbed incubation for $20 \mathrm{~h}$, cells were washed and the captured cytokine developed using a second mAb and colorimetric reagent.

$\mathrm{b}$ No antigen added to the culture.

${ }^{c}$ L. amazonensis freeze-thawed antigen added to the culture.

${ }^{\mathrm{d}}$ BABL/c PH8: BALB/c mice infected with L. amazonensis for 8 weeks; BALB/c FN: BALB/c mice infected with L. major for 8 weeks, ni: non-infected mice, v: vaccinated, $\mathrm{c}$ : infected non-vaccinated.

* $P<0.05$ wt v vs. wt c, IL12p $40^{-1-} \mathrm{c}$ and IL-12p $40^{-/-} \mathrm{v}$ by Student's $t$-test. 


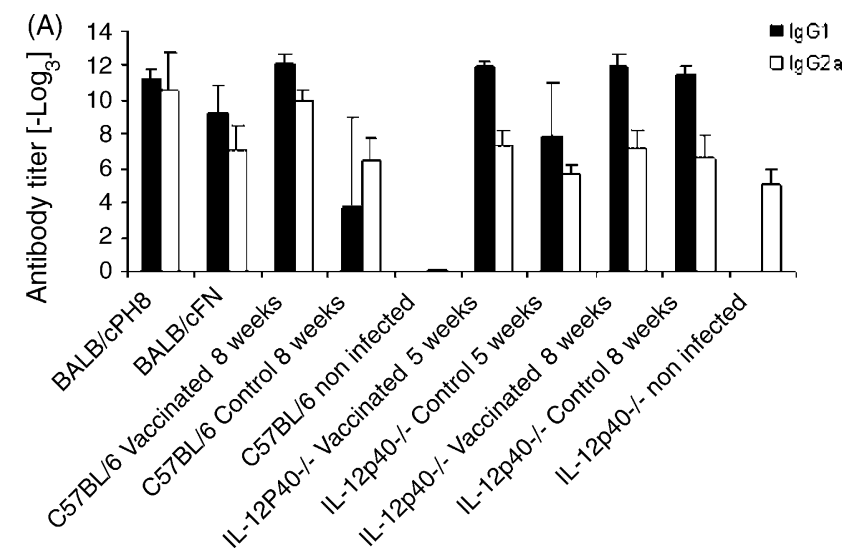

in mice in which C. parvum alone was injected along with saline. C. parvum alone did not confer protection in C57BL/6 mice (Fig. 4B), in accordance with previously published [29-31]. We then proceeded to investigate the importance of IL-12 in the immunization against $L$. amazonensis. IL-12p $40^{-1-}$ mice were vaccinated using the same protocol used for wt mice. Surprisingly, IL-12p $40^{-1-}$ were protected by the vaccination protocol for at least 4 weeks, when lesions started to grow, but were still smaller than lesions in non-vaccinated mice (Fig. 4C and D). Comparison of lesions from vaccinated and non-vaccinated IL12p $40^{-/-}$mice showed a statistically significant difference from 4 to 8 weeks post-infection (Fig. 4C and D). Moreover, in the absence of functional IL-12, vaccinated mice were able to control parasite growth more efficiently: 10,000 times fewer parasites were found in their lesions (insert Fig. 4C). C. parvum alone did not protect IL-12p $40^{-/-}$against infection with L. amazonensis (Fig. 4D). Moreover, IL-12-p40-I- mice (as well as wt) challenged 21 days after the last boost of antigen were still protected, showing that, at least for this time period, the efficacy of our vaccination protocol was lasting (Fig. 4E). Hence, in the absence of IL-12, mice could be protected by immunization with $L$. amazonensis antigens in Leishvacin in association with $C$. parvum.

Histological analysis of the infected footpad from IL$12 \mathrm{p} 40^{-1-}$ non-vaccinated mice shows an extensive vacuolated area and parasitized macrophages (Fig. 5). These areas were smaller in vaccinated IL-12p $40^{-1-}$ mice (compare Fig. 5B and D).

Fig. 3. Antibody isotypes in control and vaccinated C57BL/6 and IL-12p40-1mice after infection with $L$. amazonensis for 5 and 8 weeks. Uninfected mice are shown for comparison. Results for BALB/c mice infected with L. amazonensis (BALB/c PH8) or L. major (BALB/c FN) for 8 weeks are also shown. (A) IgG1 and $\mathrm{IgG} 2 \mathrm{a}$ were measured by incubating serially diluted sera (1:3) over wells precoated with L. amazonensis antigen, as described in Section 2. Results are expressed as the $\log _{3}$ of the antibody titer. (B) Total serum IgE was quantitated using a sandwich ELISA, as described in Section 2. Results are expressed as mean of the optical density (OD). BALB/c OVA-induced allergy mice were used as a positive control. Each bar represents mean \pm standard deviation of the mean for five animals per group. The asterisks indicate a statistically significant difference $(p \leq 0.05)$ compared with the other group.

IgE titers in IL-12p40-l- mice (Fig. 3). BALB/c mice infected with $L$. major or rendered allergic to ovalbumin were used as positive controls of a typical Th2 response [3,27,28].

Hence, IL-12p $40^{-1-}$ mice did not default to a Th2 response when infected with $L$. amazonensis.

\subsection{Vaccination of IL-12p40-/- mice against $L$. amazonensis}

IL-12 has been shown to be an adjuvant for vaccination against $L$. major [14]. Hence, we decided to investigate if IL-12 was also essential for vaccination against $L$. amazonensis. A protocol that was previously shown to protect C57BL/6 mice against infection with this parasite was used [16] and, as can be seen in Fig. 4, vaccinated wt C57BL/6 mice showed smaller lesions and smaller parasite numbers than non-vaccinated controls (Fig. 4A and insert). In order to confirm that Leishmania antigens were important for the vaccination protocol, we performed infections

\subsection{Cytokine production in vaccinated mice}

Lymph node and spleen cell cultures from wt C57BL/6 vaccinated mice presented higher levels of IFN- $\gamma$ when compared to non-vaccinated mice (Table 1) and higher numbers of IFN- $\gamma$-producing cells (Table 2). Cells from IL-12p $40^{-/-}$ mice produced practically undetectable levels of IFN- $\gamma$ in vitro, regardless of vaccination. IL-4 was not detected in supernatants from lymph node or spleen cell cultures (Table 1). In addition, no significant numbers of IL-4-producing cells were found in vaccinated wt or IL-12p40-/- (Fig. 2). The absence of significant IL-4 production was further confirmed by IgG1 and IgG2a levels, as well as by IgE levels in sera from infected mice (Fig. 3).

\section{Discussion}

IL-12 is a heterodimeric pro-inflammatory cytokine that induces production of IFN- $\gamma$ by NK cells and T cells [32]. IL-12 is critical for promoting the differentiation of naive T cells into the Th1 subset and bridges innate and adaptive immunity [33-35]. The development of a Th1 response is crucial for the protection of the host against many pathogens, including $L$. major [36-40]. Mice that are genetically deficient for the expression of IL-12 (IL-12p $40^{-/-}$) are susceptible to infection with $L$. major and default to a Th2 response [41]. Moreover, a clear requirement for IL-12 for the maintenance of a Th1 response directed to this parasite was found [42]. Thus, $L$. major-infected IL-12p $40^{-/-}$mice required continuous treatment with IL- 12 for 

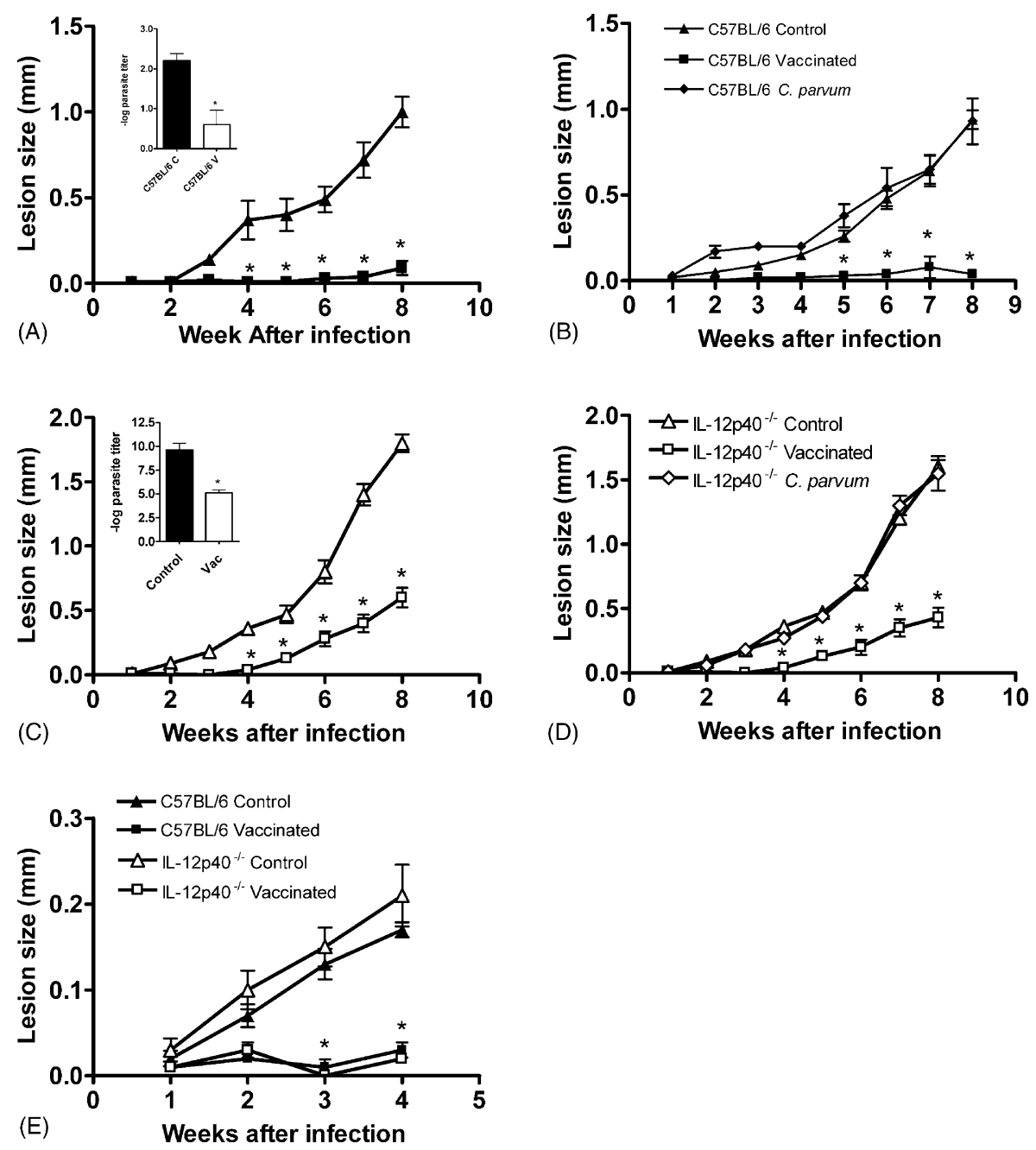

Fig. 4. Course of infection with $L$. amazonensis in vaccinated and control C57BL/6 and IL-12p40-1- mice. C. parvum was used as an adjuvant. Challenge was performed by injecting the left hind footpad with $10^{4}$ stationary-phase promastigotes. Lesion sizes were measured weekly. Each point represents the mean difference in size \pm standard deviation of the mean between infected and uninfected footpads for five mice per group at each time point. (A and C) C57BL/6 mice vaccinated and non-vaccinated controls. (B and D) IL-12p40 ${ }^{-1-}$ mice vaccinated and non-vaccinated controls. Inserts: parasite quantitation in footpad lesions 8 weeks after infection. (E) C56BL/6 and IL-12p40-/- mice vaccinated and non-vaccinated controls, challenged 21 days after the last boost of antigen. Each bar represents mean \pm standard deviation of the mean for five animals per group. The asterisks indicate a statistically significant difference $(p \leq 0.05)$ compared with the other group.

the maintenance of a Leishmania-specific Th1 response. Susceptibility in these animals was associated with a loss of the Th1 response and the development of a Th2 response [42,43].

A less clear role for the development of a Th1 response in protection is found during infection with Leishmania belonging to the mexicana complex. In one report, infection of IL-12p $40^{-/-}$ mice with L. mexicana, had the same outcome as in the wild-type controls [44]. In another study, IL-12 was critical for long-term stabilization of lesions caused by L. mexicana, but insufficient to totally cure the infection, in contrast with $L$. major infection [26]. The early control of L. mexicana infection appears to be, thus, independent of IL-12 [26]. Here, we show that IL-12p $40^{-I-}$ mice are more susceptible to infection with L. amazonensis. Similar to the study by Torrentera et al. [26], IL-12 p40 seems to be more critical to long-term stabilization of lesions. However, contrary to what was found during $L$. major infection $[41,42]$, IL-12p40 ${ }^{-1-}$ mice do not default to a Th2 response, as demonstrated by IL-4 production in vitro, by the number of IL-4-producing cells detected ex vivo and by low IgE levels. In our study, IgG1 levels did not correlate with IL-4 production. Hence, in the absence of functional IL-12, the higher susceptibility to $L$. amazonensis seems to be due to a lack of an efficient Th1 response rather than a $\mathrm{Th} 2$ response. Indeed, this was previously suggested by Afonso and Scott [4], who found that susceptibility to $L$. amazonensis in the wt C57BL/10 mouse was not due to a Th2 response, but to a lack of an efficient Th1 response.

While infection with $L$. amazonensis induced IL-12 and IFN$\gamma$ production in early stages of infection [8], infected mice fail to express a functional IL-12R [5]. This fact could explain the failure to produce sufficient IFN- $\gamma$ to control parasites to an extent that would allow lesion healing [4,5,7]. It is possible that another factor that is essential for control of parasite growth is missing in L. amazonensis-infected mice. In addition, it has been shown that IFN- $\gamma$ increases growth of $L$. amazonensis amastig- 


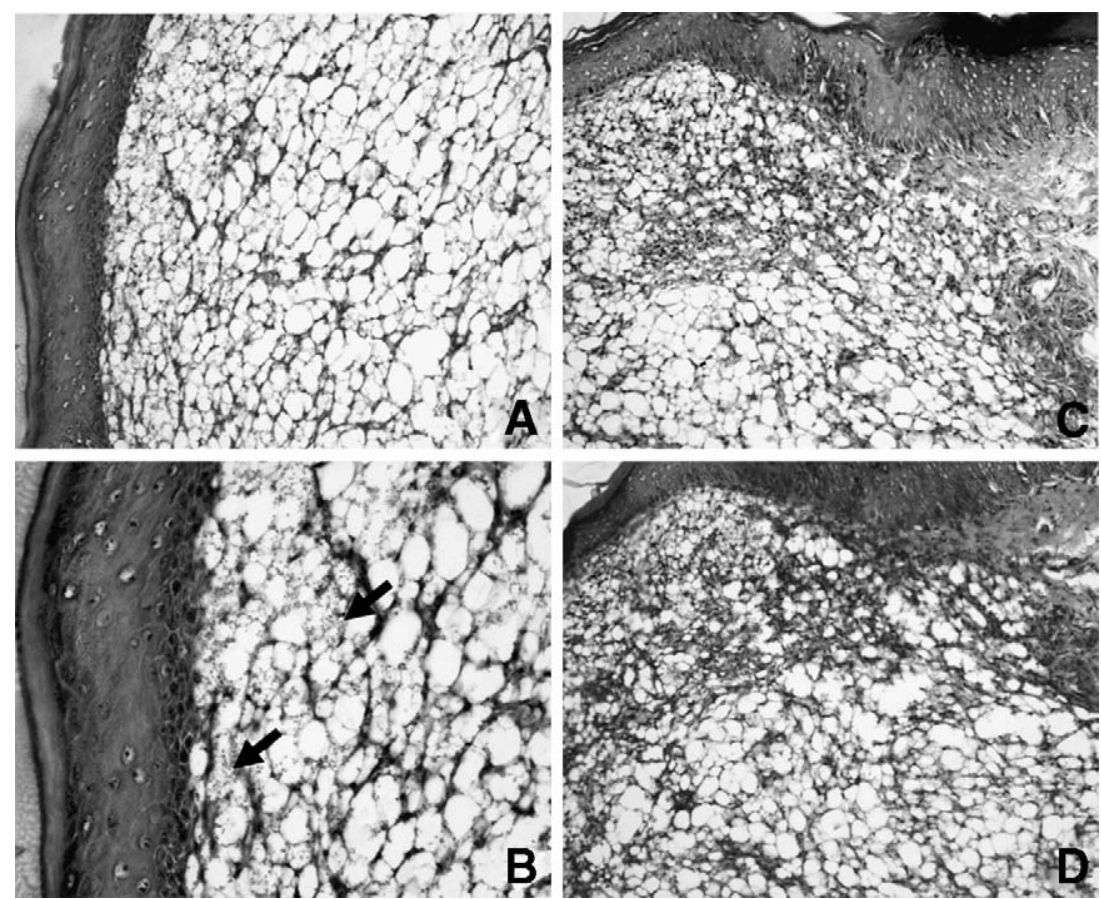

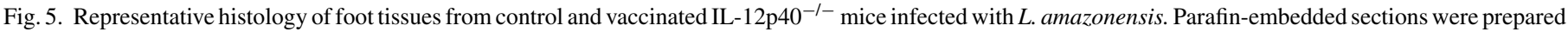

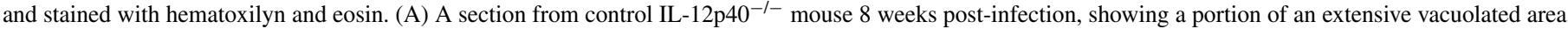

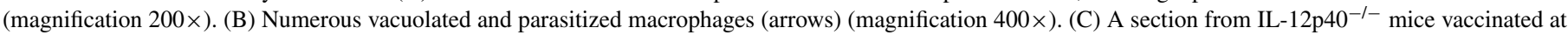

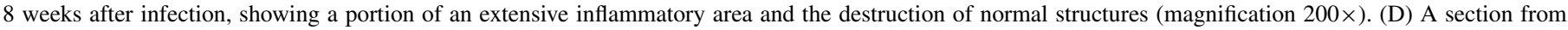
IL-12p40-1- mice vaccinated showing a limited vacuolated area compared with that in B (magnification $400 \times$ ).

otes in macrophages [45]. According to this latter report, IFN- $\gamma$ would be, in fact, favoring the maintenance of L. amazonensis in the host at the later stages of infection. However, the protective vaccination protocol used in our study induced higher levels of IFN- $\gamma$ production in wt C57BL/6 mice after challenge with L. amazonensis, when compared to non-vaccinated mice. It is possible, also, that other factors, such as TNF- $\alpha$, are being produced at higher levels in vaccinated mice. This report did not investigate these other possibilities.

The higher IFN- $\gamma$ production found in wt mice correlated with less severe disease: there was a significant decrease in the number of parasites and lesions were almost negligible. This suggests to us that the decrease in lesion size may be the result of lower parasite numbers as well as a decrease in the inflammatory response. Remarkably, histological aspects of lesions from vaccinated and non-vaccinated IL-12 $\mathrm{p} 40^{-1-}$ mice were very similar, albeit lesions in vaccinated mice were considerably smaller than non-vaccinated mice.

IL-12 is an effective adjuvant for the initiation of protective cell-mediated immunity against $L$. major, since treatment with recombinant IL-12 and parasite antigens promoted the development of Leishmania-specific $\mathrm{CD}^{+}{ }^{+} \mathrm{Th} 1$ cells and the protection of a susceptible mouse strain [14,38,40]. Moreover, IL-12 was successfully used as an adjuvant for vaccination against $L$. amazonensis $[46,47]$. Surprisingly, the early control of L. amazonensis conferred by vaccination with Leishvacin ${ }^{\circledR}$ and $C$. parvum shown here is independent of IL-12. In addition, spleen and lymph node cells from mice that were protected against infection did not produce high levels of IFN- $\gamma$ in culture upon stimula- tion with parasite antigens. IL-12 promotes the differentiation of $\mathrm{CD}^{+} \mathrm{T}$ cells into the Th1, IFN- $\gamma$-producing subtype. $\mathrm{CD}^{+} \mathrm{T}$ cells are also able to synthesize IFN- $\gamma$ but, although some evidence for a protective role played by these cells has already been accumulated, this role has been far less characterized $[48,49]$. However, it is thought that $\mathrm{CD}^{+} \mathrm{T}$ cells are also dependent on IL-12 for the production of IFN- $\gamma$ [50]. Another possible explanation for the results described here is that even in the absence of IL-12 enough Leishmania-specificTh1 cells developed in the vaccinated animals. Results from Jankovic et al. [51] demonstrate that repeated stimulation of IL-12 deficient mice induced low levels of IFN- $\gamma$-producing- $\mathrm{CD} 4^{+} \mathrm{T}$ cells. It is possible that the repeated inoculation of antigens in our vaccination protocol was sufficient to induce the development of a number of Th1 cells capable of partially controlling the infection. However, these cells were not detected in ELISPOT assays. Hence, the mechanism for resistance to infection after vaccination in IL-12p40 $40^{-1-}$ mice is still obscure, and is under investigation in our laboratory.

Here, we used vaccinated mice to study the mechanisms of resistance against L. amazonensis. Although in wild-type mice vaccination conferred protection, as measured by the parasite burden and the size of lesions, and this protection correlated with higher levels of IFN- $\gamma$, the absence of IL-12 p40 did not prevent the vaccination protocol from protecting mice. Hence, although IL-12p $40^{-/-}$mice were more susceptible to infection, protection was conferred by the vaccination protocol. The mechanisms involving this protection are, at present, unknown. 


\section{Acknowledgements}

This work was supported by FAPEMIG grant number REC 32011/99. MXHS and TAB are fellows of CAPES. LQV, WLT and LCCA are fellows of CNPq. The authors are indebted to Biobrás S.A. for providing Leishvacin, to Antônio Mesquita Vaz for animal care, to Dr. Josely Lannes Vieira and Josué da Costa Lima Junior (FioCruz, Rio de Janeiro, Brazil) for the use of the Immunospot image analyzer, Dr. Denise Carmona Cara for the sera from allergic mice and Dr. Ricardo T. Gazzinelli for the reagents for the ELISPOT assays.

\section{References}

[1] Neva F, Sacks D, Leishmaniasis. Trop Geogr Med 1990:296-308.

[2] Almeida RP, Barral-Netto M, De Jesus AM, De Freitas LA, Carvalho EM, Barral A. Biological behavior of Leishmania amazonensis isolated from humans with cutaneous, mucosal, or visceral leishmaniasis in BALB/C mice. Am J Trop Med Hyg 1996;54(2):178-84.

[3] Sacks D, Noben-Trauth N. The immunology of susceptibility and resistance to Leishmania major in mice. Nat Rev Immunol 2002;2(11):845-58.

[4] Afonso LC, Scott P. Immune responses associated with susceptibility of C57BL/10 mice to Leishmania amazonensis. Infect Immun 1993;61(7):2952-9.

[5] Jones DE, Buxbaum LU, Scott P. IL-4-independent inhibition of IL12 responsiveness during Leishmania amazonensis infection. J Immunol 2000;165(1):364-72.

[6] Jones DE, Ackermann MR, Wille U, Hunter CA, Scott P. Early enhanced Th1 response after Leishmania amazonensis infection of C57BL/6 interleukin-10-deficient mice does not lead to resolution of infection. Infect Immun 2002;70(4):2151-8.

[7] Soong L, Xu JC, Grewal IS, Kima P, Sun J, Longley BJ, et al. Disruption of CD40-CD40 ligand interactions results in an enhanced susceptibility to Leishmania amazonensis infection. Immunity 1996;4(3):263-73.

[8] Oliveira MA, Santiago HC, Lisboa CR, Ceravollo IP, Trinchieri G, Gazzinelli RT, et al. Leishmania sp: comparative study with Toxoplasma gondii and Trypanosoma cruzi in their ability to initialize IL-12 and IFN-gamma synthesis. Exp Parasitol 2000;95(2):96-105.

[9] Barral-Netto M, Von Sohsten RL, Teixeira M, dos Santos WL, Pompeu ML, Moreira RA, et al. In vivo protective effect of the lectin from Canavalia brasiliensis on BALB/c mice infected by Leishmania amazonensis. Acta Trop 1996;60(4):237-50.

[10] Soong L, Chang CH, Sun J, Longley Jr BJ, Ruddle NH, Flavell RA, et al. Role of CD4+ T cells in pathogenesis associated with Leishmania amazonensis infection. J Immunol 1997;158(11):5374-83.

[11] Terabe M, Kuramochi T, Ito M, Hatabu T, Sanjoba C, Chang KP, et al. CD4+ cells are indispensable for ulcer development in murine cutaneous leishmaniasis. Infect Immun 2000;68(8):4574-7.

[12] Silveira FT, Lainson R, Shaw JJ, De Souza AA, Ishikawa EA, Braga RR. Cutaneous leishmaniasis due to Leishmania (Leishmania) amazonensis in Amazonian Brazil, and the significance of a negative Montenegro skin-test in human infections. Trans Roy Soc Trop Med Hyg 1991;85(6):735-8.

[13] Pirmez C, Yamamura M, Uyemura K, Paes-Oliveira M, Conceicao-Silva F, Modlin RL. Cytokine patterns in the pathogenesis of human leishmaniasis. J Clin Invest 1993;91(4):1390-5.

[14] Afonso LC, Scharton TM, Vieira LQ, Wysocka M, Trinchieri G, Scott P. The adjuvant effect of interleukin-12 in a vaccine against Leishmania major. Science 1994;263(5144):235-7.

[15] Antunes CM, Mayrink W, Magalhaes PA, Costa CA, Melo MN, Dias M, et al. Controlled field trials of a vaccine against New World cutaneous leishmaniasis. Int J Epidemiol 1986;15(4):572-80.

[16] Costa CA, Afonso LCC, Toledo VPCP, Tavares CAP, Genaro O, Mayrink W. Evaluation of an industrialized non-living promastig- ote vaccine against cutaneous leishmaniasis. Parassitologia 1992;34: 45-51.

[17] Mayrink W, Da Costa CA, Magalhaes PA, Melo MN, Dias M, Lima AO, et al. A field trial of a vaccine against American dermal leishmaniasis. Trans Roy Soc Trop Med Hyg 1979;73(4):385-7.

[18] Scott P, Pearce E, Natovitz P, Sher A. Vaccination against cutaneous leishmaniasis in a murine model. II. Immunologic properties of protective and nonprotective subfractions of soluble promastigote extract. J Immunol 1987;139(9):3118-25.

[19] De Luca PM, Mayrink W, Alves CR, Coutinho SG, Oliveira MP, Bertho $\mathrm{AL}$, et al. Evaluation of the stability and immunogenicity of autoclaved and nonautoclaved preparations of a vaccine against American tegumentary leishmaniasis. Vaccine 1999;17(9/10):1179-85.

[20] Marzochi KB, Marzochi MA, Silva AF, Grativol N, Duarte R, Confort EM, et al. Phase 1 study of an inactivated vaccine against American tegumentary leishmaniasis in normal volunteers in Brazil. Mem Inst Oswaldo Cruz 1998;93(2):205-12.

[21] Mayrink W, Williams P, Da Costa CA, Magalhaes PA, Melo MN, Dias $M$, et al. An experimental vaccine against American dermal leishmaniasis: experience in the State of Espirito Santo, Brazil. Ann Trop Med Parasitol 1985;79(3):259-69.

[22] Mendonca SC, De Luca PM, Mayrink W, Restom TG, Conceicao-Silva F, Da Cruz AM, et al. Characterization of human T lymphocytemediated immune responses induced by a vaccine against American tegumentary leishmaniasis. Am J Trop Med Hyg 1995;53(2):195201.

[23] Courret N, Prina E, Mougneau E, Saraiva EM, Sacks DL, Glaichenhaus N, et al. Presentation of the Leishmania antigen LACK by infected macrophages is dependent upon the virulence of the phagocytosed parasites. Eur J Immunol 1999;29(3):762-73.

[24] Vieira LQ, Goldschmidt M, Nashleanas M, Pfeffer K, Mak T, Scott P. Mice lacking the TNF receptor p55 fail to resolve lesions caused by infection with Leishmania major, but control parasite replication. J Immunol 1996;157(2):827-35.

[25] Heinzel FP, Rerko RM, Ahmed F, Pearlman E. Endogenous IL-12 is required for control of Th2 cytokine responses capable of exacerbating leishmaniasis in normally resistant mice. J Immunol 1995;155(2): 730-9.

[26] Torrentera FA, Glaichenhaus N, Laman JD, Carlier Y. T-cell responses to immunodominant LACK antigen do not play a critical role in determining susceptibility of BALB/c mice to Leishmania mexicana. Infect Immun 2001;69(1):617-21.

[27] Lu XZ, Liu XM, Guo YC, Yang XG. Assessment of the BALB/c mice as a suitable animal model for the investigation of food allergy. Wei Sheng Yan Jiu 2005;34(2):211-3.

[28] Zhao Y, van Hasselt CA, Woo KS, Wong YO, Liang CY, Leung PC. Establishment of a modified intranasally ovabumin induced animal model of allergic rhinitis. Zhonghua Er Bi Yan Hou Tou Jing Wai Ke Za Zhi 2005;40(3):176-80.

[29] Cardoso SR, da Silva JC, da Costa RT, Mayrink W, Melo MN, Michalick MS, et al. Identification and purification of immunogenic proteins from nonliving promastigote polyvalent Leishmania vaccine (Leishvacin). Rev Soc Bras Med Trop 2003;36(2):193-9.

[30] Colmenares M, Kima PE, Samoff E, Soong L, Mahon-Pratt D. Perforin and gamma interferon are critical CD8+ T-cell-mediated responses in vaccine-induced immunity against Leishmania amazonensis infection. Infect Immun 2003;71(6):3172-82.

[31] Kar S, Metz C, Mahon-Pratt D. CD4+ T cells play a dominant role in protection against New World leishmaniasis induced by vaccination with the P-4 amastigote antigen. Infect Immun 2005;73(6): 3823-7.

[32] Gately MK, Renzetti LM, Magram J, Stern AS, Adorini L, Gubler $\mathrm{U}$, et al. The interleukin-12/interleukin-12-receptor system: role in normal and pathologic immune responses. Annu Rev Immunol 1998;16: 495-521.

[33] Hsieh CS, Macatonia SE, Tripp CS, Wolf SF, O’Garra A, Murphy KM. Development of TH1 CD4+ T cells through IL-12 produced by Listeriainduced macrophages. Science 1993;260(5107):547-9. 
[34] Manetti R, Parronchi P, Giudizi MG, Piccinni MP, Maggi E, Trinchieri $\mathrm{G}$, et al. Natural killer cell stimulatory factor (interleukin 12 [IL12]) induces $\mathrm{T}$ helper type 1 (Th1)-specific immune responses and inhibits the development of IL-4-producing Th cells. J Exp Med 1993;177(4):1199-204.

[35] Manetti R, Gerosa F, Giudizi MG, Biagiotti R, Parronchi P, Piccinni MP, et al. Interleukin 12 induces stable priming for interferon gamma (IFNgamma) production during differentiation of human $\mathrm{T}$ helper ( $\mathrm{Th}$ ) cells and transient IFN-gamma production in established Th2 cell clones. J Exp Med 1994;179(4):1273-83.

[36] Belosevic M, Finbloom DS, Van Der Meide PH, Slayter MV, Nacy CA. Administration of monoclonal anti-IFN-gamma antibodies in vivo abrogates natural resistance of $\mathrm{C} 3 \mathrm{H} / \mathrm{HeN}$ mice to infection with Leishmania major. J Immunol 1989;143(1):266-74.

[37] Decken K, Kohler G, Palmer-Lehmann K, Wunderlin A, Mattner F, Magram $J$, et al. Interleukin-12 is essential for a protective Th1 response in mice infected with Cryptococcus neoformans. Infect Immun 1998;66(10):4994-5000.

[38] Heinzel FP, Schoenhaut DS, Rerko RM, Rosser LE, Gately MK. Recombinant interleukin 12 cures mice infected with Leishmania major. J Exp Med 1993;177(5):1505-9.

[39] Scott P. IFN-gamma modulates the early development of Th1 and Th2 responses in a murine model of cutaneous leishmaniasis. J Immunol 1991;147(9):3149-55.

[40] Sypek JP, Chung CL, Mayor SE, Subramanyam JM, Goldman SJ, Sieburth DS, et al. Resolution of cutaneous leishmaniasis: interleukin 12 initiates a protective T helper type 1 immune response. J Exp Med 1993;177(6):1797-802.

[41] Mattner F, Magram J, Ferrante J, Launois P, Di Padova K, Behin R, et al. Genetically resistant mice lacking interleukin-12 are susceptible to infection with Leishmania major and mount a polarized Th2 cell response. Eur J Immunol 1996;26(7):1553-9.

[42] Park AY, Hondowicz BD, Scott P. IL-12 is required to maintain a Th1 response during Leishmania major infection. J Immunol 2000;165(2):896-902.
[43] Scott P, Artis D, Uzonna J, Zaph C. The development of effector and memory $\mathrm{T}$ cells in cutaneous leishmaniasis: the implications for vaccine development. Immunol Rev 2004;201(1):318-38.

[44] Buxbaum LU, Uzonna JE, Goldschmidt MH, Scott P. Control of New World cutaneous leishmaniasis is IL-12 independent but STAT4 dependent. Eur J Immunol 2002;32(11):3206-15.

[45] Qi H, Ji J, Wanasen N, Soong L. Enhanced replication of Leishmania amazonensis amastigotes in gamma interferon-stimulated murine macrophages: implications for the pathogenesis of cutaneous leishmaniasis. Infect Immun 2004;72(2):988-95.

[46] Coelho EAF, Tavares CAP, Carvalho FAA, Chaves KF, Teixeira KN, Rodrigues RC, et al. Immune responses induced by the Leishmania (Leishmania) donovani A2 antigen, but not by the LACK antigen, are protective against experimental Leishmania (Leishmania) amazonensis infection. Infect Immun 2003;71(7):3988-94.

[47] Kenney RT, Sacks DL, Sypek JP, Vilela L, Gam AA, Evans-Davis K. Protective immunity using recombinant human IL-12 and alum as adjuvants in a primate model of cutaneous leishmaniasis. J Immunol 1999;163(8):4481-8.

[48] Belkaid Y, Von SE, Mendez S, Lira R, Caler E, Bertholet S, et al. $\mathrm{CD} 8+\mathrm{T}$ cells are required for primary immunity in C57BL/6 mice following low-dose, intradermal challenge with Leishmania major. J Immunol 2002;168(8):3992-4000.

[49] Chan MM. T cell response in murine Leishmania mexicana amazonensis infection: production of interferon-gamma by CD8+ cells. Eur $\mathrm{J}$ Immunol 1993;23(5):1181-4.

[50] Chang J, Cho JH, Lee SW, Choi SY, Ha SJ, Sung YC. IL-12 priming during in vitro antigenic stimulation changes properties of CD8 T cells and increases generation of effector and memory cells. J Immunol 2004;172(5):2818-26.

[51] Jankovic D, Kullberg MC, Hieny S, Caspar P, Collazo CM, Sher A. In the absence of IL-12, CD4(+) T cell responses to intracellular pathogens fail to default to a Th2 pattern and are host protective in an IL-10(-/-) setting. Immunity 2002;16(3):429-39. 